\title{
RU'TGERS MANUSCRIPT SOURCES RELATING TO THE AFRICAN-AMERICAN COMMUNITY IN NEW JERSEY
}

\author{
BY RONALD L. BECKER
}

Ronald L. Becker is Head, Special Collections, Rutgers University Libraries

\section{9 th Century Holdings}

Special Collections and University Archives at the Rutgers University Libraries holds several manuscript collections relating to the AfricanAmerican experience in New Jersey. One of the earliest holdings is a volume of minutes of the African Association of New Brunswick. The minute book dates from 1817 to 1824. The Association was founded to provide funds for a school in Parsippany, N.J., organized by the Presbyterian Synod of New York and New Jersey. The goal of the school was to educate "Young Men of Colour to be Teachers and Preachers to People of Colour within theses States and elsewhere." Included in the volume are the Association's constitution, a list of subscribers, receipts, certificates of permission to join, and texts of addresses delivered before the Association by Jeremiah Gloucester of Philadelphia (January 1, 1820) and Augustavus Cesar (January 1, 1821).

Rutgers also holds the records of the New Brunswick Colonization Society which include its minutes, memberships lists, and constitutions. The Society was active in 1838-1839 and revived in 1853-1854.

There are collections that relate directly to slavery in New Jersey as well as to the lives of free African-Americans during the pre-Civil War period. The records of Middlesex County, N.J., include a volume of slave manumission records, 1800-1825, and a volume recording the births of Black children in the county, 1804-1844. The manumission register's entries include the name (and sometimes age) of the freed slave, the date of manumission, and the name and residence of the person registering the manumission. The volume is indexed by the name of person freed. Entries in the birth register include the name and sex of the child, the mother's given name, the name of the person reporting the birth, and the dates that the birth was reported and recorded. The Peter Still Papers (Burlington County, N.J.) include correspondence, 1850-1875, relating to the purchase of his wife and family held as slaves in Alabama and to the publication of his biography. The collection also includes a Still family genealogy, 1798-1821. 
Several diaries contain entries concerning slavery and education of African-American youths. The diary of general store keeper John Mason Brown (born 1801) includes several entries in December 1834 relating to a fugirive slave case in Salem, N.J. The diary of Garret Conover Schenck (1829-1859) includes observations on slavery. Schenck was the son of a Franklin Park, N.J., physician, judge, congressman, and farmer. The younger Schenck's diary dates from 1851 to 1854 when he was a student at Rutgers College (1851) and a law student in Newark, N.J. The diary of Susan Whitney (born 1839) includes entries describing her teaching of a small class of Black children in Perth Amboy, N.J. The diary of Samuel Allinson (1808-1883) records many years of the life of a Quaker philanthropist, active in temperance, anti-slavery, and prison reform work. The entries for 1824-1829 are detailed and informative; those for 1830-1883 are generally brief and concerned chiefly with farming in Yardville, N.J. The How Family Papers include the personal and theological correspondence (1810-1867) of Presbyterian clergyman Samuel B. How, much of which relates to his anti-abolition pamphlet, Slaveholding Not Sinful (1855).

The genealogical collections contain information on Black families in New Jersey. The U.S. Census population schedules for New Jersey are available on microfilm for each decade from 1830 through 1920 with the exception of 1890 . For the 1830 and 1840 census schedules, it is noted whether Black residents are slave or free. Other information includes name (head of household only for 1830 and 1840, entire household thereafter); sex, age, color, birthplace of individual (later of parents also), marital status, whether literate, whether in school, etc. The New Jersey State Census was taken in the middle of each decade from 1855 through 1915 and is also available on microfilm. The information provided is similar to that of the U.S. Census.

Two collections document the participation of African-American citizens in the Civil War. The journal of Henry Whitney (born 1844) details the life of a lieutenant in the 45th Regiment, U.S. Colored Troops, 1864-1865 and includes the recruiting of Black soldiers, the behavior of Blacks and Southern Whites, as well as details concerning the Free Military School for Applicants for Command of Colored Troops in Philadelphia and Whitney's former students there. The Papers of Simon Peters Selover (1845-1915) relate in part to his service as a musician in Company $\mathrm{C}$ of the 26th Regiment, U.S. Colored Infantry, 1864-1865, and to an application for a pension. After the Civil War, Selover lived successively in New Brunswick and Asbury Park, N.J.

Also included in the Rutgers collection are slave bills of sale and broadsides dealing with issues surrounding slavery. The broadsides, together with many books and pamphlets relating to the New Jersey AfricanAmerican experience are enumerated in Donald A. Sinclair's The Negro and New Jersey: A Checklist of Books, Pamphlets, Official Publications, Broadsides, 
and Dissertations, 1754-1964 in the Rutgers University Library (New Brunswick, N.J., 1965). Relevant pictorial materials include a set of 18 tintypes depicting African-Americans probably taken in Asbury Park, N.J.

\section{The Ernest Thompson Papers}

Rutgers University Libraries'Special Collections and University Archives is fortunate to hold the papers of community leader and labor organizer Ernest Thompson. Thompson was born in Baltimore on August 7, 1907, and until the age of thirteen lived with his parents and four sisters and brothers on his grandfather's farm on the Eastern Shore of Maryland. From there, he went to live with an aunt in Jersey City where he worked during the day and attended school at night. He narrowly escaped death while working on the construction of the Holland Tunnel: he had to be hospitalized with the "bends." While there, he learned that his entire crew had been killed in an accident. He then found factory employment for the next nineteen years with the American Radiator Company in Bayonne.

At the American Radiator Company, Thompson began his long career in labor and community organizing. He helped found an independent union and was elected president in 1940, a position which he held for the next twelve years. Under his leadership, the union first joined the American Federation of Labor (AFL), but later affiliated with the United Electrical, Radio and Machine Workers of American (UE) one of the leading left-wing militant unions in the Congress of Industrial Organizations (CIO). In 1943, he became the first African-American to serve as a field organizer for the UE. In that capacity, he conducted campaigns in northern New Jersey and Baltimore. His political activities were launched in 1942 when he was named executive director of the Hudson County Industrial Union Council. For the next eight years, he toiled to develop political power for the workers in the region and ran campaigns for candidates in city, county, and state government elections. During the same period (1946-1950), he served as business manager for UE locals in Jersey City and Bayonne.

The success of Thompson's work in New Jersey led to his appointment as executive director of the UE National Fair Practices Committee. In that capacity, he forged a coalition of Blacks and women to develop training programs to prepare minority and female workers to advance to leadership positions. During this period, he also helped found the National Negro Labor Council which grew to over 50,000 members in 53 cities. Thompson wrote the keynote address for its first convention. Through his speeches, writings, and travels in conjunction with the Council and his national UE office, he articulated the role of the Black worker in the struggle for economic, political, and social equality. As the Council's Director of Organization, he led campaigns against discrimination in employment throughout the country. Thompson's labor activities continued until 1956 when the Council was disbanded under pressure from the government's Subversive 
Activities Control Board. That same year, his position as executive director of the UE National Fair Practices Committee was terminated when the membership in the New York - New Jersey area left the UE for the CIO's International Union of Electronic, Electrical, Salaried, Machine \& Furniture Workers (IUE). A description of New Jersey civil rights material within the IUE Archives (also at Rutgers Special Collections and University Archives) follows.

With his career as a labor leader at an end, Thompson moved to Orange, N.J., and immediately became involved in community and educational activities in Essex, Union, and Hudson Counties which he continued until his death in 1971. In Orange (Essex County), he founded the Citizens for Representative Government (CRG) in the East Ward in 1958 and served as its director of organization. His efforts led to the passage of a referendum to change the form of city government to that of a mayor and council, with the city council consisting of seven members to be elected every four years: three at-large, and one from each of the four wards. As a result, there was Black political representation in Orange's wards for the first time, including the election of the first Black city councilman and the first Black school board president. Soon each ward developed its own organization similar to the CRG. To coordinate these efforts, Thompson founded and served as director of the Amalgamated Organizations for Good Government in 1965, thereby uniting Black political power in the city. He also served as program director of the Orange Higher Achievement Tutoring Program and executive director of the Foundation for Negro Progress.

In 1968, Thompson founded the Tri-City Citizens Union for Progress and served as chair of its organization and membership committees. In 1969, Tri-City, which had operations in Essex, Hudson, and Union Counties, established the Amity Village rehabilitation and cooperative housing projects in Newark.

Thompson's skills as a labor leader and organizer were recognized in his appointment as labor advisor to the Newark Coordinating Council in 1964. The following year, he represented the Council on its negotiating committee which lobbied for equal employment opportunities at the Rutgers University Newark Campus and the Newark College of Engineering construction sites. As part of this effort, he mobilized the Black elected officials of Essex County, as well as the Attorney General and Governor of New Jersey. His work led to the desegregation of many of the trades through strict enforcement of civil rights laws.

The Ernest Thompson Papers at Rutgers document all of his major activities and include the National Negro Labor Council File (1951-1970), the UE Fair Practices Committee File (1944-1958), the Citizens for Representative Government File (1953-1970) and a general file documenting his other New Jersey activities (1943-1969). The National Negro Labor Council material consists of papers relating to conventions, labor 
campaigns, and the U.S. Subversive Activities Control Board. Included are yearbooks, speeches, resolutions, leaflets, correspondence, transcripts of radio programs, legal papers, photographs, and press releases. There are also transcripts of Paul Robeson's address to the Council and of a meeting between Thompson, Coleman Young and others at a 1970 reunion of Council members in Newark.

The UE Fair Practices Committee material pertains to conventions and conferences, women and Negro workers, and campaigns against General Electric, Ford, and International Harvester. Included are reports, transcripts of radio broadcasts and plays, correspondence, minutes, legal papers, newsletters, broadsides, memoranda, and resolutions.

The Citizens for Representative Government material documents campaign organizing for local elections and housing issues, and against school district gerrymandering. Included are press releases, campaign leaflets, correspondence, notes, position papers, and newspaper clippings.

The material in the General File documents Thompson's other activities in New Jersey organizations and issues such as housing rehabilitation, anti-poverty programs, apprenticeship training, and public school education. Organizations represented include the Amalgamated Organizations for Good Government, the Committee for Negro Progress in '66, the Foundation for Negro Progress, the National Association of Negro Trade Unionists (of New Jersey), the Orange Higher Achievement Tutoring Program, the Newark Coordinating Council, and the Tri-City Citizens Union for Progress. The Newark Coordinating Council file relates to its efforts to end discriminatory hiring practices by unions and contractors at construction sites. In addition, there are writings of Thompson's daughter Mindy, which include drafts of Thompson's biography Homeboy Comes to Newark, and The National Negro Labor Council: A History. An unpublished finding guide provides folder-level access to all of the materials in the Ernest Thompson Papers.

Special Collections and University Archives also holds the John W. Alexander Papers. Dr. Alexander served from 1964 to 1968 as the first Black president of the Orange, N.J., Board of Education. In 1964, Orange was a suburb with an approximately 25 percent minority population and a low median income among its residents. Alexander's papers document his efforts to implement change in the school system with respect to the traditionally underprivileged. Among the projects reflected in the papers are the proposed (1966-1968) construction of a new comprehensive high school, a complete curriculum revision from kindergarten through twelfth grade, an enhancement of vocational education, and in-service educational courses for teachers. There is also a file documenting his efforts to desegregate the existing school system, including correspondence, reports, speeches, testimony, news clippings, fliers, petitions, legal documents, and 
minutes. All of the files reflect Alexander's ongoing responsibilities as mediator between school administrators, city government and the population of Orange, and long range goals which he authored or assisted in implementing.

\section{New Jersey Civil Rights Material within the IUE Archives}

The International Union of Electronic, Electrical, Salaried, Machine \& Furniture Workers, AFL-CIO (IUE) Archives contains a treasure trove of sources documenting labor's contribution to the modern civil rights movement (1949-1970s). As a union juggernaut in race relations, fair employment practices, and equal opportunity programs, the IUE established and administered one of the most ambitious and activist civil rights programs of any American labor organization-extending from the national office down to the district and local levels. Virtually every IUE department (President's Office, Secretary-Treasurer's Office, Legal, Legislative) assumed functional responsibility for advancing civil rights and monitoring compliance with IUE, state, and federally-mandated fair employment guidelines. Though a substantial portion of the archives' holdings on civil rights are national in scope, there are supplementary records which focus exclusively on New Jersey districts and locals. Black leadership within New Jersey IUE locals and districts played a pivotal role in establishing key committees, conferences, and programs which shaped the civil rights legislative agenda and contributed to social empowerment.

The district files of the IUE Civil Rights Committee (1950-1960s) contain the most authoritative source material pertaining to the civil rights activities of the New Jersey affiliates of the IUE. Chaired by IUE SecretaryTreasurer Al Hartnett, this key committee formulated and directed the union's national civil rights program, including the establishment of parallel civil rights committees at the district and local level. Its primary objective was to achieve local compliance with national IUE civil rights policies and resolutions. The committee placed a priority on districts administering their own regional programs and facilitating participation in grassroots civil rights efforts. National IUE Civil Rights Committee Conference records are fairly extensive with verbatim minutes, speeches, and resolutions. Material documenting district and local civil rights activities are interspersed throughout the collection but are mostly concentrated in two areas: inclusion in the IUE Civil Rights Bulletin - the official organ of the IUE Civil Rights Committee - and the District IUE Civil Rights Committee Files.

For New Jersey locals, the best sources for documenting civil rights activities are contained within the District Four (North-Central N.J. Locals) and District One (South-Camden Locals) files of the IUE Civil Rights Committee. These files contain press clippings, agendas, summaries of meetings, resolutions, district publications (District 4 IUE-CIO News), and 
reports covering regional and local activities on behalf of civil rights, human relations, and equal employment opportunity. The focus is largely on AfricanAmerican and Hispanic workers and the IUE's cooperative civil rights efforts with the Urban League of New Jersey, the New Jersey Chapter of NAACP, and the New Jersey State CIO Industrial Union Council.

There are additional files which pertain to the programs of the IUE District Fair Employment Practices and Anti-Discrimination Committees. Items include correspondence, conference material, and committee memoranda which chronicle district and local union efforts to implement and enforce anti-discrimination clauses within union contracts. Such issues as the expansion of job opportunities for minorities within the electronics and electrical industries and non-discrimination in hiring, promotions, and seniority provisions are highlighted.

Labor education seminars and conferences sponsored by the IUE Education Department and Civil Rights Committee yielded important documentation of the civil rights education movement and its positive impact on intraunion race relations. Many of the IUE's summer labor institutes were held on the campus of Rutgers University during the 1950s and 1960s. The IUE archives contains program material and educational kits distributed to participants of the institutes.

\section{University Archives Holdings Relating to African-American Students at Rutgers}

The Rutgers University Archives serves as the final repository for the institution's historical records. Its primary purpose is to document the history of the University and to provide source material for those who seek to evaluate the impact of the institution's activities on the history of American social, cultural, and intellectual development. Included are the records of the major administrative and academic offices, and the schools, colleges, divisions, and institute's on the New Brunswick, Newark, and Camden campuses. In addition, there are significant collections of personal papers of faculty, students, and alumni; and records of student organizations, photographs, architectural materials, and memorabilia. One of the most important of the Archives' holdings is a Paul Robeson Collection which contains correspondence, scrapbooks, articles, newspaper clippings, movie and play reviews, tributes, photographs, and sound recordings that document Robeson's student days and illustrious career. Materials in the collection date from 1916 when Robeson entered Rutgers until 1981, five years following his death.

The University Archives also holds an abundance of material relating to activities of Black students at Rutgers during the late 1960s and to programs that were established as a result. There are a group of interviews conducted by Professor and University Historian Richard P. McCormick with Black student leaders and others that were involved in student demonstrations in New Brunswick, Newark, and Camden in 1969. Also 
included are the records generated by Eve Remson Saches, coordinator of "Challenge '69," a year-long celebration of Black student protest on all three campuses throughout that year. The records of the Urban University Program (1969-1972) which also emerged as a result of the student activities trace its development on all three campuses and include correspondence, reports, press releases, and other documentation regarding personnel, administration, admissions, and budget. The records of various administrative offices (President, Provost, Dean of Rutgers College) and the minutes of the University Board of Governors and Board of Trustees document the response of the administration and governing bodies to the student movement and the establishment of academic programs such as Afro-American Studies and also deal with such issues as residence life, extra-curricular activities, and the establishment of Livingston College and other programs including the Equal Opportunity Fund. 